\title{
Germination and vigor of linseed seeds under different conditions of light, temperature and water stress
}

\section{Germinação e vigor de sementes de linhaça sob diferentes condições de luz, temperatura e estresse hídrico}

\author{
Raquel Stefanello ${ }^{1 *}$; Bruna Boucinha Viana²; Luiz Augusto Salles das Neves ${ }^{3}$
}

\begin{abstract}
Linseed (Linum usitatissimum L.), cultivated from seeds, is one of the oldest plants domesticated by humans and is popularly used as a medicine. It can be used as the raw material to produce oil and bran because it has high lipids content, fiber and proteins. Based on the economic potential of this species and the need for more information about its physiology, the goal of this study was to analyze the effects of light, temperature and water stress on the germination and vigor of linseed seeds. In experiment I the seeds were sown on paper at constant temperatures of $15,20,25$ and $30{ }^{\circ} \mathrm{C}$ in the presence and absence of light. In experiment II, the seeds were placed on paper germitest soaked in solutions of polyethylene glycol (PEG 6000) at osmotic potentials corresponding to zero, $-0.10,-0.20,-0.30,-0.40,-0.50$ and $-0.60 \mathrm{MPa}$. To evaluate the physiological potential, the following tests were made: germination, first germination count, length and dry mass of seedlings, and water stress. It was found that the highest percentages of germination and vigor occurred at a constant temperature of $20^{\circ} \mathrm{C}$, both in the presence and absence of light. The reduction of the osmotic potential of the substrate promoted a significant decrease in the germination and vigor of the linseed seeds. Osmotic potentials equal or less than -0.30 MPa were harmful to germination and there was no normal seedling development starting at $-0.50 \mathrm{MPa}$. Key words: Linum usitatissimum. Physiological quality. Polyethylene glycol.
\end{abstract}

\section{Resumo}

A linhaça (Linum usitatissimum L.), cultivada através de sementes, é uma das plantas mais antigas domesticadas pelo homem, utilizada popularmente como medicamento. Pode ser empregada como matéria-prima na produção de óleo e farelo por possuir alto teor de lipídios, fibras e proteínas. Diante do potencial econômico da espécie e da necessidade de informações sobre sua qualidade fisiológica, objetivou-se analisar o efeito da luz, temperatura e estresse hídrico na germinação e no vigor de sementes de linhaça. No experimento I, as sementes foram semeadas sobre papel nas temperaturas constantes de $15,20,25$ e $30^{\circ} \mathrm{C}$ na presença e ausência de luz. No experimento II, as sementes foram colocadas sobre papel embebido em soluções de polietileno glicol (PEG 6000) nos potenciais osmóticos correspondentes a zero; $-0,10 ;-0,20 ;-0,30 ;-0,40 ;-0,50 ;-0,60 \mathrm{MPa}$. Para avaliação do potencial fisiológico foram realizados os testes de: germinação, primeira contagem de germinação, comprimento e massa seca de plântulas e estresse hídrico. As maiores percentagens de germinação e vigor ocorreram quando da temperatura constante de $20^{\circ} \mathrm{C}$, tanto na presença quanto na ausência de luz. A redução do potencial osmótico do substrato causou decréscimo significativo na germinação e no vigor das sementes de linhaça. Potenciais osmóticos iguais ou inferiores a $-0,30 \mathrm{MPa}$ foram prejudiciais à germinação não havendo desenvolvimento de plântulas normais a partir de -0,50 MPa.

Palavras-chave: Linum usitatissimum. Qualidade fisiológica. Polietileno glicol.

\footnotetext{
${ }^{1}$ Bióloga, Dr ${ }^{\mathbf{a}}$ em Agronomia, Departamento de Biologia, Universidade Federal de Santa Maria, UFSM, Santa Maria, RS, Brasil. E-mail: raquelstefanello@yahoo.com.br

${ }^{2}$ Discente, Curso de Zootecnia, UFSM, Santa Maria, RS, Brasil. E-mail: brunnavw@hotmail.com

${ }^{3}$ Eng $^{\circ}$ Agr $^{\circ}$, Prof. Dr., Departamento de Biologia, UFSM, Santa Maria, RS, Brasil. E-mail: snaugusto@gmail.com

* Author for correspondence
} 


\section{Introduction}

Linum usitatissimum, popularly known as linseed, is a plant cultivated by seeds in cold and hot climates, and is part of the group of oilseeds (PARIZOTO et al., 2013). Linseed can be used as raw material in the production of oil and bran, and possess high oil (40-45\%), fiber and protein (20$25 \%$ ) content (RABETAFIKA et al., 2011).

In the last years, this seed has become important in diets due to the health benefits it provides, for example, it reduces the risk of cardiovascular disease because it helps control blood cholesterol and blood glucose levels, as well as body weight. In addition, linseed ingested in small amounts during the day reduces the risk of cancer and diabetes; the high linolenic acid content in the oil has an anticarcinogenic property (COSMO et al., 2014).

Seed germination can be affected by internal, external or environmental factors (LUZ et al., 2014). The sensitivity of seeds to light is highly variable according to the species, where there are seeds that are positively, negatively or not affected by this factor, which is called positive, negative and neutral photoblastic, respectively (CARVALHO; NAKAGAWA, 2012; TAIZ; ZEIGER, 2013).

Temperature, on the other hand, influences both the percentage and velocity of germination because it influences the absorption of water and biochemical reactions (CARVALHO; NAKAGAWA, 2012). Many studies have demonstrated that light and temperature interfere with seed germination of different species, such as the following: Linum usitatissimum L. (O'CONNOR; GUSTA, 1994; SAEIDI; ROWLAND, 1999; KURT; BOZKURT, 2006; KURT, 2010); Ipomea grandifolia (Dammer) O'Done (ORZARI et al., 2013); Murdannia nudiflora (L.) Brenans (LUZ et al., 2014); Piptadenia stipulacea (Benth.) Ducke (NOGUEIRA et al., 2014); Ocimum basilicum L. (KHAN et al., 2014); Plantago psyllium L., Althaea officinalis L., Nigella sativa L. (JAMIAN et al., 2014); Orobanche crenata Forsk. (MORAL et al., 2015);
Euryodendron excelsum H. T. Chang (SHEN et al., 2015); and Salvia hispanica L. (STEFANELLO et al., 2015).

In addition to light and temperature, water is fundamental for the initiation of germination because the seed must attain a certain water content to germinate. Seeds respond to different quantities of water in the substrate and an excess of water can promote or inhibit germination (CARDOSO, 2012). Studies related to water are important to the knowledge of seed biology. Some works have been conducted using solutions of polyethylene glycol (PEG 6000) with different osmotic potentials of wet substrates, generally paper, where the seeds are sown trying to simulate conditions of low water availability in soil (ALMEIDA et al., 2014; NOGUEIRA et al., 2014; GORDIN et al., 2015; LAVEZO et al., 2015; MORAL et al., 2015; NAIM; AHMED, 2015; SHEN et al., 2015). PEG is an osmotic agent without adverse effect on seeds, is chemically inert, non-toxic and has a high molecular weight; therefore, it is difficult to absorb and can restrict water from seeds, depending on the concentration, to simulate dry conditions (VILLELA et al., 1991).

Despite a considerable increase in what is known about the use of linseed, information about the germination of its seeds is still scarce. This species is worthy of study, not only because of its nutritional importance, but also because an evaluation of the physiological quality of its seeds will provide useful knowledge to elucidate the germination process. Based on this, the objective of the present work was to evaluate the effects of light, temperature and water stress on the germination and vigor of linseed (Linum usitatissimum L.) seeds.

\section{Material and Methods}

This study used brown linseed seeds (Linum usitatissimum L., family Linaceae) that were acquired from a company in the municipality of Guarani das Missões (RS - Brazil) that produces and sells seeds. 
To evaluate the effect of light and temperature on physiological potential, the linseed seeds were submitted to the presence and absence of light at constant temperatures of $15,20,25$ and $30{ }^{\circ} \mathrm{C}$ (JAMIAN et al., 2014; KHAN et al., 2014; LUZ et al., 2014; NOGUEIRA et al., 2014; MORAL et al., 2015; SHEN et al., 2015). To test the presence of light, the seeds were put in a germination chamber set for $8 \mathrm{~h}$ of light and 16 hours or darkness, respectively. To test the absence of light, the seeds were sown in an illuminated room with a safety filter made of three green cellophane layers and maintained in the dark throughout the test by covering the plastic germination boxes with two layers of aluminum paper. Florescent light bulbs $(20 \mathrm{~W})$, with a radiant flux density of $15 \mathrm{mmol} . \mathrm{m}^{-}$ ${ }^{2} \cdot \mathrm{s}^{-1}$, were used to generate the light conditions in the germination chambers.

The physiological potential of the seeds was evaluated using the following tests:

Germination test (\%): made with eight replicates of 50 seeds distributed in plastic boxes (gerbox) on three layers of filter paper moistened with distilled water at a proportion of 2.5 times the weight of the paper. After sowing the seeds, the plastic boxes (gerbox) were maintained at temperatures of 15 , 20, 25 and $30{ }^{\circ} \mathrm{C}$, and counts were made on day 6 and day 10 (when the test ended). The results were expressed in percentage of normal and abnormal seedlings (BRASIL, 2009).

First count (\%): made together with the germination test, which determined the percentage of normal and abnormal seedlings on the sixth day of the test (BRASIL, 2009).

Length of the seedlings: normal seedlings were obtained from sowing four replicates of 20 seeds. Paper rolls containing seeds were placed in a growth chamber for six days, at temperatures of 15, 20, 25 and $30{ }^{\circ} \mathrm{C}$. Subsequently, 10 seedlings from each replicate were evaluated for length using a ruler in millimeters. The average length of the seedlings was obtained by summing the averages of each replicate and dividing by the number of normal seedlings measured, with the results expressed in centimeters per seedling (NAKAGAWA, 1999).

Dry mass of seedlings: first, the fresh weight was obtained of 10 previously measured seedlings, for four replicates, and then maintained in papers bags in a dryer at a temperature of $60{ }^{\circ} \mathrm{C}$ until reaching a constant weight (48 h). Subsequently, the seedlings were weighed on a precision balance (to $0.001 \mathrm{~g}$ ) and the results were expressed in milligrams per seedling (NAKAGAWA, 1999).

Water stress: a constant temperate of $20{ }^{\circ} \mathrm{C}$, the presence of light and a paper substrate soaked in an aqueous solution of polyethylene glycol (PEG 6000 ), at concentrations corresponding to zero, $-0.10,-0.20,-0.30,-0.40,-0.50,-0.60 \mathrm{MPa}$, was used. Level zero was the control and was distilled water. The quantity of the solution needed to obtain the osmotic potentials was based on Villela et al. (1991).

Water stress was evaluated by means of the germination and first count tests, according to what was described above and by the germination speed index (GSI). For the latter, germinated seeds were counted daily at the same time. The criterion for germination was the protrusion of the radicle and the germination speed index was calculated based on the formula in Maguire (1962).

For the two experiments, the experimental design was completely randomized. In the first, the treatments were a factorial of 4 x 2 (4 temperatures $\mathrm{x}$ presence or absence of light), and in the second there were 6 treatments comprising the osmotic potential levels. The germination and primary count variables were transformed into arc sen $(X / 100)^{1 / 2}$. For the analysis of variance, the $\mathrm{F}$ test was employed. When this was significant, comparisons among the averages were made using the SkottKnott test, at 5\% probability (qualitative variables) and by regression (quantitative variables), using the software SISVAR (FERREIRA, 2000). 


\section{Results and Discussion}

\section{Experiment I: Effect of light and temperature on the physiological potential of linseed seeds}

Based on the data analysis of the seed germination of linseed, there was no significant different for the two light conditions (Table 1). This species can be classified as indifferent to light, or neutral photoblastic, because it germinates regardless of the light regime (CARVALHO; NAKAGAWA, 2012; ORZARI et al., 2013; TAIZ; ZEIGER, 2013).

Table 1. Percentage of germination (normal and abnormal seedlings) and first germination count of linseed (Linum usitatissimum L.) seeds under different temperatures in the presence (PL) and absence of light (AL).

\begin{tabular}{ccccccc}
\hline \multirow{2}{*}{ Temperature } & \multicolumn{2}{c}{ Normal seedlings (\%) } & \multicolumn{2}{c}{ Abnormal seedlings (\%) } & \multicolumn{2}{c}{ First cont (\%) } \\
\cline { 2 - 6 } & PL & AL & PL & AL & PL & AL \\
\hline $15^{\circ} \mathrm{C}$ & $68 \mathrm{~b} \mathrm{~A}^{*}$ & $70 \mathrm{~b} \mathrm{~A}$ & $16 \mathrm{~b} \mathrm{~A}$ & $13 \mathrm{~b} \mathrm{~A}$ & $44 \mathrm{~b} \mathrm{~A}$ & $31 \mathrm{c} \mathrm{B}$ \\
$20^{\circ} \mathrm{C}$ & $79 \mathrm{a} \mathrm{A}$ & $78 \mathrm{a} \mathrm{A}$ & $13 \mathrm{~b} \mathrm{~A}$ & $11 \mathrm{~b} \mathrm{~A}$ & $54 \mathrm{a} \mathrm{A}$ & $54 \mathrm{a} \mathrm{A}$ \\
$25^{\circ} \mathrm{C}$ & $68 \mathrm{~b} \mathrm{~A}$ & $67 \mathrm{~b} \mathrm{~A}$ & $10 \mathrm{~b} \mathrm{~A}$ & $7 \mathrm{c} \mathrm{A}$ & $52 \mathrm{a} \mathrm{A}$ & $41 \mathrm{~b} \mathrm{~B}$ \\
$30^{\circ} \mathrm{C}$ & $38 \mathrm{c} \mathrm{A}$ & $42 \mathrm{c} \mathrm{A}$ & $31 \mathrm{a} \mathrm{A}$ & $19 \mathrm{a} \mathrm{B}$ & $27 \mathrm{c} \mathrm{A}$ & $30 \mathrm{c} \mathrm{A}$ \\
\hline
\end{tabular}

* Means followed by same letter in each column, and capital letters on each line, do not differ by the Scott Knott test at $5 \%$ probability.

In relation to temperature, higher percentages of normal seedlings were observed at a temperature of $20^{\circ} \mathrm{C}$, both in the presence and absence of light (Table 1). Similar results were obtained when germinating the seeds of green pepper basil Ocimum selloi Benth. (COSTA et al., 2010), cordade-viola -Ipomoea grandifolia (Dammer) O'Donell (ORZARI et al., 2013), basil - Ocimum basilicum L. (KHAN et al., 2014), Marrubium vulgare L. (DADACH et al., 2015), Orobanche crenata Forsk. (MORAL et al., 2015), Euryodendron excelsum $\mathrm{H}$. T. Chang (SHEN et al., 2015) and Salvia hispanica L. (STEFANELLO et al., 2015).

At a temperature of $30{ }^{\circ} \mathrm{C}$, in the presence of light, most of the seedlings obtained were abnormal $(31 \%)$ with a poorly developed primary root and short, necrotic epicotyl (Table 1). Similar results were observed by Gordin et al. (2012) where a temperature of $30{ }^{\circ} \mathrm{C}$ produced abnormal plants of niger (Guizotia abyssinica Cass.) that had a root and/ or epicotyl with a primary infection and a twisted and curved hypocotyl. According to Castro et al. (1997), high temperatures can negatively influence plant development, mainly under conditions of low water availability. This condition can modify the stability of cell membranes, affecting different metabolic processes, especially photosynthesis and cell respiration (TAIZ; ZEIGER, 2013). Very high temperatures can negatively influence seed germination of some species by denaturing proteins essential to the germination process (DOUSSEAU et al., 2008; OLIVEIRA et al., 2014), which reduces the percentage of normal plants, as observed in this study.

In relation to vigor, significant interaction between light and temperature was verified. In the first germination count (Table 1) the percentage of normal seedlings was higher in the presence of light at the temperatures of 20 and $25{ }^{\circ} \mathrm{C}(54$ and $52 \%$, respectively) and in the absence of light at $20{ }^{\circ} \mathrm{C}$ (54\%). Similar results under these conditions were found by Koefender et al. (2009) for the common marigold (Calendula officinalis), Costa et al. (2010) for green pepper basil (Ocimum selloi), Orzari et al. (2013) for corda-de-viola (Ipomoea grandifolia), Khan et al. (2014) for basil (Ocimum basilicum) and Stefanello et al. (2015) for chia (Salvia hispanica). According to Carvalho and Nakagawa (2012), 
temperature strongly influences germination, and the optimal temperature is where the seed expresses its maximum germination potential in the least amount of time.

In relation to the length of the linseed seedlings (Table 2), the analysis of variance showed there was significant interaction between the factors analyzed. The longest seedlings were grown in the absence of light at temperatures of 20 and $25{ }^{\circ} \mathrm{C}$ (15.31 and $15.08 \mathrm{~cm}$, respectively) and in the presence of light at $20^{\circ} \mathrm{C}(13.01 \mathrm{~cm})$. The highest values of dry mass were obtained at a temperature of $20^{\circ} \mathrm{C}$ in the presence $(3.87 \mathrm{mg})$ and absence $(3.75 \mathrm{mg})$ of light. Similar results were found by Stefanello et al. (2015) for seeds of the chia (Salvia hispanica L.) under white light at a temperature of $20^{\circ} \mathrm{C}$. However, in another study the dry mass of seedlings of niger (Guizotia abyssinica Cass.) were not influenced by the substrates tested, and were higher when grown at $15{ }^{\circ} \mathrm{C}$, followed by temperatures of $20-30{ }^{\circ} \mathrm{C}$ and $25^{\circ} \mathrm{C}$ (GORDIN et al., 2012).

Table 2. Length $(\mathrm{cm})$ and dry weight $(\mathrm{mg})$ of linseed (Linum usitatissimum L.) seedlings exposed to different temperatures in the presence and absence of light.

\begin{tabular}{ccccc}
\hline \multirow{2}{*}{ Temperature } & \multicolumn{2}{c}{ Length of seedlings $(\mathrm{cm})$} & \multicolumn{2}{c}{ Dry mass of seedlings $(\mathrm{mg})$} \\
\cline { 2 - 5 } & Presence of light & Absence of light & Presence of light & Absence of light \\
\hline $15^{\circ} \mathrm{C}$ & $7.64 \mathrm{c} \mathrm{B}$ & $10.73 \mathrm{~b} \mathrm{~A}$ & $3.45 \mathrm{~b} \mathrm{~A}$ & $3.52 \mathrm{~b} \mathrm{~A}$ \\
$20^{\circ} \mathrm{C}$ & $13.01 \mathrm{a} \mathrm{B}$ & $15.31 \mathrm{a} \mathrm{A}$ & $3.87 \mathrm{a} \mathrm{A}$ & $3.75 \mathrm{a} \mathrm{A}$ \\
$25^{\circ} \mathrm{C}$ & $10.39 \mathrm{~b} \mathrm{~B}$ & $15.08 \mathrm{a} \mathrm{A}$ & $3.32 \mathrm{~b} \mathrm{~A}$ & $3.42 \mathrm{~b} \mathrm{~A}$ \\
$30^{\circ} \mathrm{C}$ & $8.31 \mathrm{c} \mathrm{B}$ & $10.12 \mathrm{~b} \mathrm{~A}$ & $3.32 \mathrm{~b} \mathrm{~A}$ & $3.42 \mathrm{~b} \mathrm{~A}$ \\
\hline
\end{tabular}

* Means followed by same letter in each column, and capital letters on each line, do not differ by the Scott Knott test at 5\% probability.

Experiment II: Effect of water stress on the physiological potential of linseed seeds

In the absence of polyethylene glycol, the seeds had an average germination of $81 \%$ (Figure 1A) and there was a sharp reduction for the other concentrations; starting at $-0.30 \mathrm{MPa}$ the values were less than $50 \%$.

The results of this work corroborate works that studied Cucumis melo L. (SOHRABIKERTABAD et al., 2013), Piptadenia stipulacea (Benth.) Ducke (NOGUEIRAetal.,2014), niger-Guizotiaabyssinica Cass. (GORDIN et al., 2015), Petiveria alliacea L. (LAVEZO et al., 2015), Orobanche crenata Forsk. (MORAL et al., 2015), Cicer arietinum L. (NAIM; AHMED, 2015) and Euryodendron excelsum $\mathrm{H}$. T. Chang (SHEN et al., 2015), which also found a reduction in germination percentage when the polyethylene glycol concentration increased. In addition, for seeds of Amburana cearensis A. C. Smith, Almeida et al. (2014) found that exposure to PEG, starting at $-0.6 \mathrm{MPa}$, limited the germination and formation of normal seedlings.

According to Carvalho and Nakagawa (2012) and Cardoso (2012), when water does not enter the seed (imbibition) there is no metabolic reaction, which inhibits respiratory and enzymes activities, protein synthesis, digestion of reserves, translocation and assimilation, embryo growth, rupturing of the tegument, growth of the radicle and, consequently, the formation of the seedling. In addition, water deficiency in the medium can totally inhibit germination, as observed for the higher concentrations of polyethylene glycol tested in this study. 
Figure 1. Percentage of germination (A), first count (B) and germination speed index (C) of linseed seeds under different osmotic potentials in a polyethylene glycol solution (PEG 6000).

A.

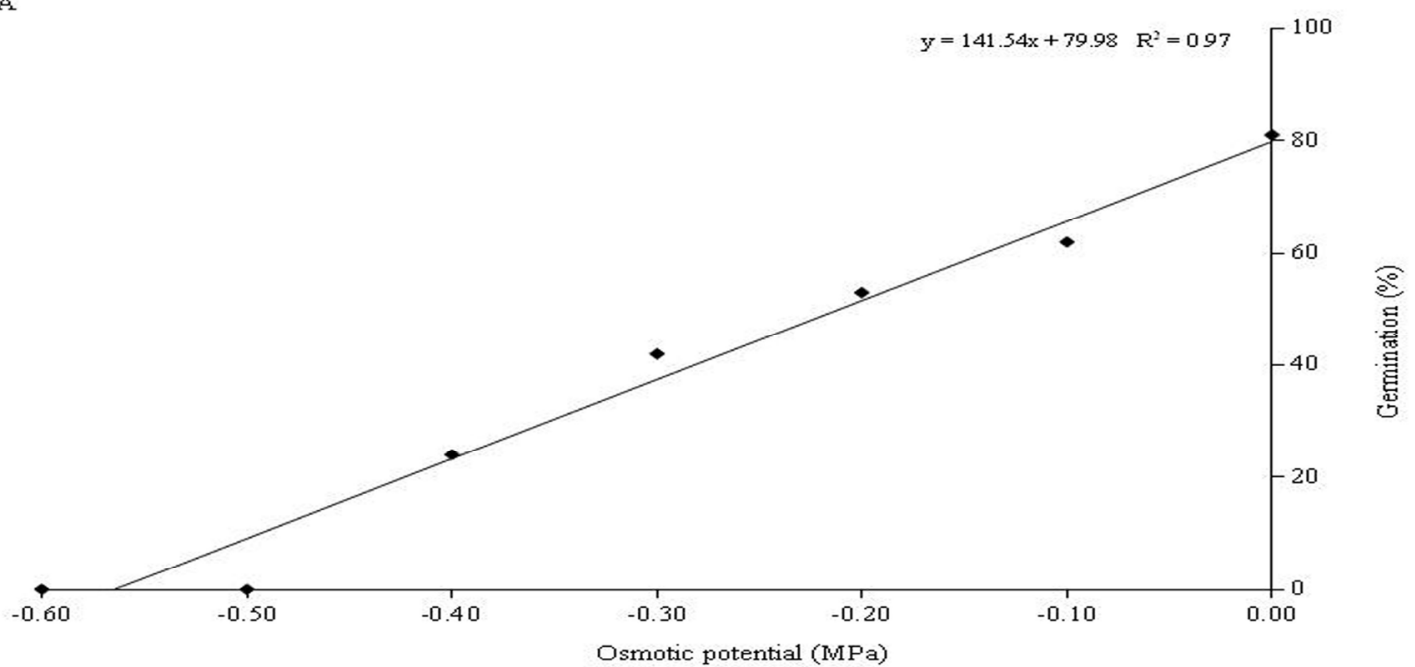

B

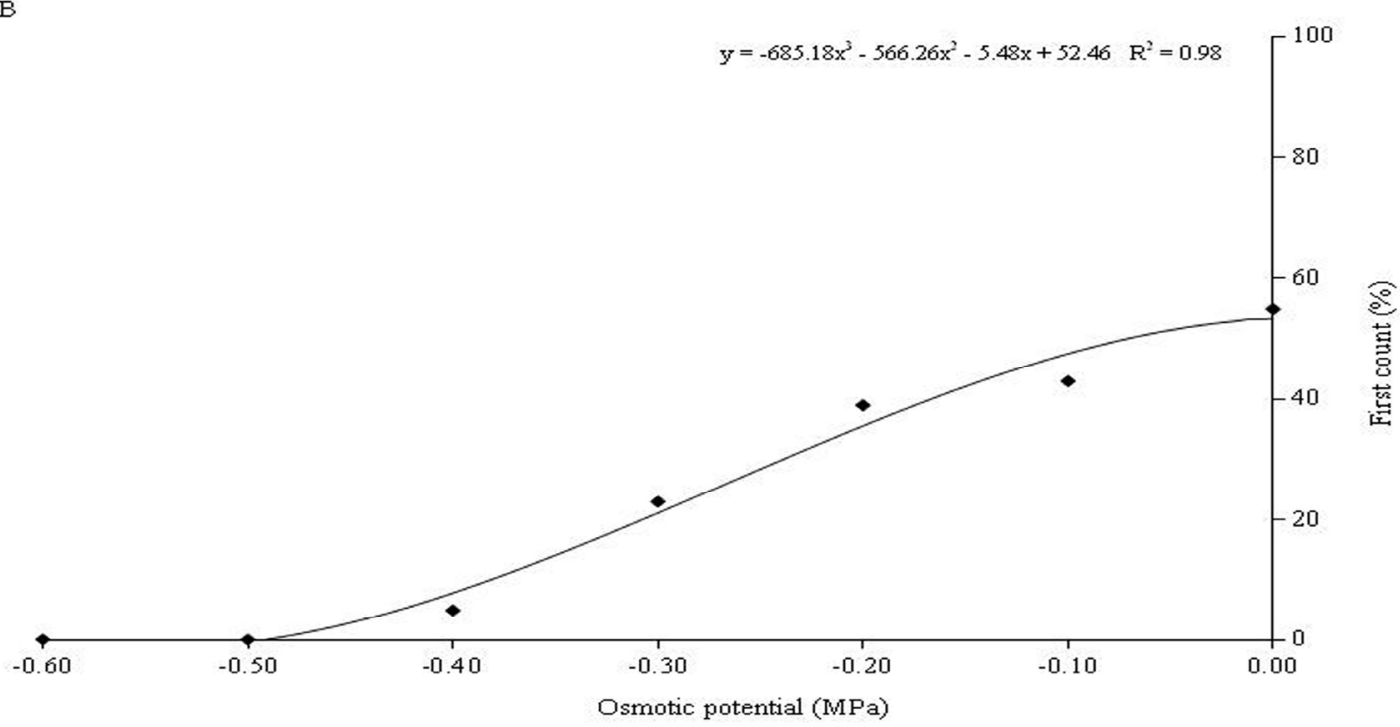

$\mathrm{C}$

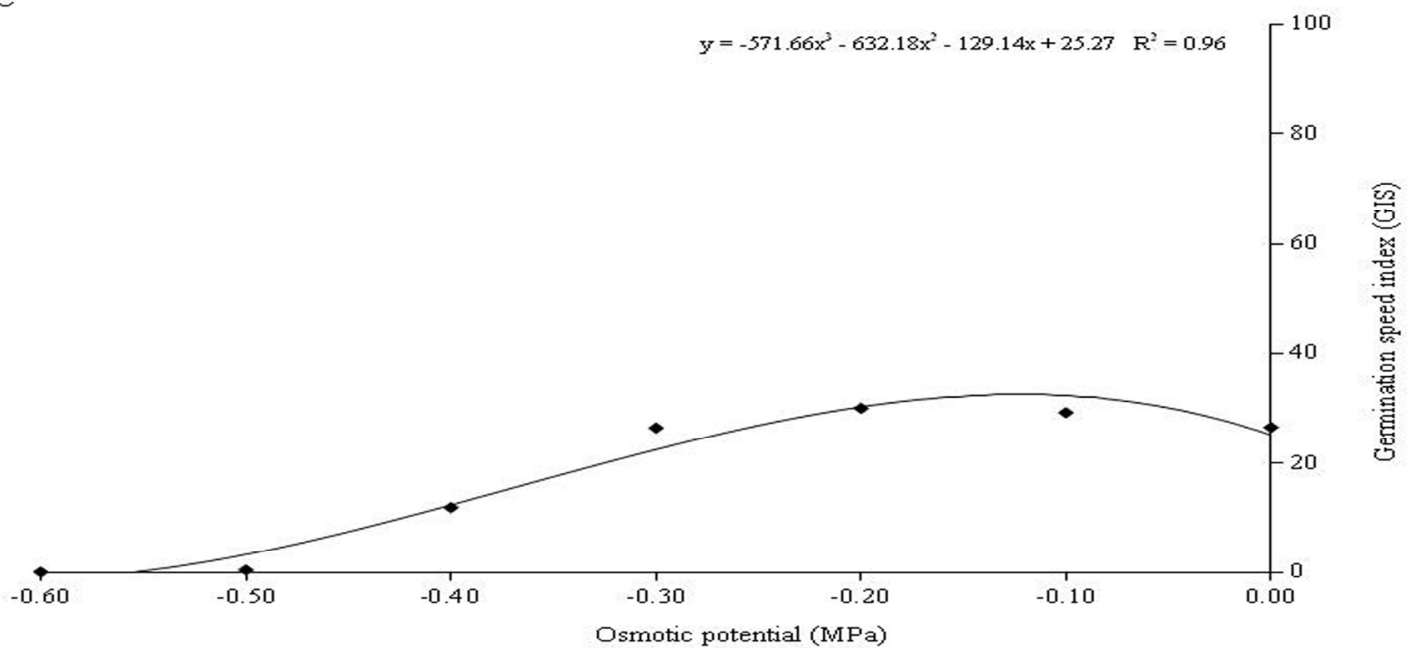


The vigor of the seeds evaluated by the first count of germination and by the germination speed index (Figure 1B e 1C) was reduced when the osmotic potential of the solution decreased. A reduction of the germination velocity was found according to an increase in PEG in the substrate. For seeds of pinhão-manso (Jatropha curcas L.), Andréo-Souza et al. (2010) also observed that that germination velocity was the first parameter affected by the decreased availability of water, causing the process of germination to take more time. According to Cardoso (2012), pre-soaking seeds in an osmotic solution, principally polyethylene glycol, inhibits the quantity and velocity of entering water and impedes the radicle from protruding.

\section{Conclusions}

For the linseed seeds, the highest germination and vigor percentages were observed for seeds kept at a constant temperature of $20^{\circ} \mathrm{C}$, both in the presence and absence of light.

The reduction of the osmotic potential of the substrate caused a significant decrease in the germination and vigor of the linseed seeds. Osmotic potentials below $-0.3 \mathrm{MPa}$ were harmful to the germination and there was no normal development of the seedlings starting at $-0.5 \mathrm{MPa}$.

\section{References}

ALMEIDA, J. P. N.; PINHEIRO, C. L.; LESSA, B. F. T.; GOMES, F. M.; MEDEIROS FILHO, S. Estresse hídrico e massa de sementes na germinação e crescimento de plântulas de Amburana cearensis (Allemão) A.C. Smith. Revista Ciência Agronômica, Ceará, v. 45, n. 4, p. 777787, 2014.

ANDRÉO-SOUZA, Y.; PEREIRA, A. L.; SILVA, F. F. S.; RIBEIRO-REIS, R. C.; EVANGELISTA, M. R. V.; CASTRO, R. D.; DANTAS, B. F. Efeito da salinidade na germinação de sementes e no crescimento inicial de mudas de pinhão-manso. Revista Brasileira de Sementes, Londrina, v. 32, n. 2, p. 83-92, 2010.

BRASIL. Ministério da Agricultura, Pecuária e Abastecimento. Regras para análise de sementes. Secretaria de Defesa Agropecuária. Brasília: Mapa, ACS, 2009. 399 p.
CARDOSO, V. J. M. Germinação. In: KERBAUY, G. B. Fisiologia vegetal. Guanabara Koogan: Rio de Janeiro, 2012. p. 386-408.

CARVALHO, N. M.; NAKAGAWA, J. Sementes: ciência, tecnologia e produção. 5. ed. Jaboticabal: Funep, 2012. $590 \mathrm{p}$.

CASTRO, C.; CASTIGLIONI, V. B. R.; BALLA, A.; LEITE, R. M. V. B. C.; KARAM, D.; MELLO, H. C.; GUEDES, L. C. A.; FARIAS, J. R. B. A cultura do girassol. Londrina: EMBRAPA-CNPSo. 1997. 36 p. (EMBRAPA-CNPSo. Circular técnica, 13).

COSMO, B. M. N.; CABRAL, A. C.; PINTO, L. P.; FRIGO, J. P.; AZEVEDO, K. D.; BONASSA, G. Linhaça Linum usitatissimum: suas características. Revista Brasileira de Energias Renováveis, Palotina, v. 3, n. 3, p. 189-196, 2014.

COSTA, L. C. B.; PINTO, J. E. B. P.; BERTOLUCCI, S. V. B.; GUIMARÃES, R. M. Qualidade fisiológica de sementes de Ocimum selloi Benth sob condições de luz, temperatura e tempo de armazenamento. Ciência e Agrotecnologia, Lavras, v. 34, n. 3, p. 675-680, 2010.

DADACH, M.; MEHDADI, Z.; LATRECHE, A. Germination responses of Marrubium Vulgare L. under various water stress conditions. Journal of Applied Environmental and Biological Sciences, v. 5, n. 9, p. 2833, 2015.

DOUSSEAU, S.; ALVARENGA, A. A.; ARANTES, L. O.; OLIVEIRA, D. M.; NERY, F. C. Germinação de sementes de tanchagem (Plantago tomentosa Lam.): influência da temperatura, luz e substrato. Ciência e Agrotecnologia, Lavras, v. 32, n. 2, p. 438-443, 2008.

FERREIRA, D. F. Manual do sistema Sisvar para análises estatísticas. Lavras: UFLA, 2000. 69 p.

GORDIN, C. R. B.; MARQUES, R. F.; MASETTO, T. E.; SCALON, S. P. Q. Germinação, biometria de sementes e morfologia de plântulas de Guizotia abyssinica Cass. Revista Brasileira de Sementes, Londrina, v. 34, n. 4 p. 619-627, 2012.

GORDIN, C. R. B.; SCALON, S. P. Q.; MASETTO, T. E. Disponibilidade hídrica do substrato e teor de água da semente na germinação de niger. Pesquisa Agropecuária Tropical, Goiânia, v. 45, n. 3, p. 312-318, 2015.

JAMIAN, S. S.; ASILAN, K. S.; MEHRANI, S.; TABRIZI, A. T.; GOHARIAN, A. Effects of elevated temperatures on seed germination and seedling growth in three medicinal plants. International Journal of Agriculture and Crop Sciences, London, v. 7, n. 4, p. 173177, 2014.

KHAN, A. R.; SAEED, M.; SHAHWANI, M. N.; AHMED, N.; RAZA, A. M.; KAKAR, M. A. Ecophysiology of seed germination in native and exotic 
labiates of Balochistan. Biologia, v. 60, n. 1, p. 23-29, 2014.

KOEFENDER, J.; MENEZES, N. L.; BURIOL, G. A.; TRENTIN, R.; CASTILHOS, G. Influência da temperatura e da luz na germinação da semente de calêndula. Horticultura Brasileira, Brasília, v. 27, n. 2, p. 207-210, 2009.

KURT, O. Effects of chilling on germination in flax (Linum usitatissimum L.). Turkish Journal of Field Crops, Konak-Izmir, v. 15, n. 2, p. 159-163, 2010.

KURT, O.; BOZKURT, D. Effect of temperature and photoperiod on seedling emergence of flax (Linum usitatissimum L.). Journal of Agronomy, Madison, v. 5, n. 3, p. 541-545, 2006

LAVEZO, A.; BRAGA, L. F.; BATISTÃO, A. C.; BONFANTE, L. V. Estresse osmótico na germinação de sementes de Petiveria alliacea L. Revista Brasileira de Plantas Medicinais, Campinas, v. 17, n. 4, p. 622-630, 2015.

LUZ, F. N.; YAMASHITA, O. M.; FERRARESI, D. A.; CARVALHO, M. A. C.; CAMPOS, O. R.; KOGA, P. S.; MASSAROTO, J. A. Interferência de luz, temperatura, profundidade de semeadura e palhada na germinação e emergência de Murdannia nudiflora. Comunicata Scientiae, Piauí, v. 5, n. 1, p. 26-33, 2014.

MAGUIRE, J. D. Speed of germination-aid in selection and evaluation for seedling emergence and vigor. Crop Science, Madison, v. 2, n. 2, p. 176-177, 1962.

MORAL, J.; LOZANO-BAENA, M. D.; RUBIALES, D. Temperature and water stress during conditioning and incubation phase affecting Orobanche crenata seed germination and radicle growth. Frontiers in Plant Science, Lausanne, v. 6, n. 408, p. 1-10, 2015.

NAIM, A. H.; AHMED, F. E. Interactive effect of temperature and water stress induced by polyethylene glycol (PEG) on germination and recovery of two chickpea (Cicer arietinum L.) cultivars. Open Access Library Journal, Irvine, v. 2, n. 10, p. 1-7, 2015.

NAKAGAWA, J. Testes de vigor baseados no desempenho de plântulas. In: KRZYZANOWSKI, F. C.; VIEIRA, R. D.; FRANÇA NETO, J. B. (Ed.). Vigor de sementes: conceitos e testes. Londrina: ABRATES, 1999. cap. 2, p. 2-24.

NOGUEIRA, F. C. B.; BEZERRA, M. L.; PINHEIRO, C. L.; BRITO, S. F.; MEDEIROS FILHO, S. Piptadenia stipulacea (Benth.) Ducke seed germination in response to temperature, light and water stress. American Journal of Plant Sciences, Irvine, v. 5, n. 26, p. 3796-3804, 2014.

O'CONNOR, B. J.; GUSTA, L. V. Effect of low temperature and seeding depth on the germination and emergence of seven flu (Linum usitatissimum L.) cultivars. Canadian Journal of Plant Science, Ottawa, v. 74, n. 2, p. 247-253, 1994.

OLIVEIRA, S. S. C.; MARTINS, C. C., CRUZ, S. J. S.; SILVA, C. J. Seleção de progênies de nabo-forrageiro para germinação sob altas temperaturas. Ciência Rural, Santa Maria, v. 44, n. 2, p. 217-222, 2014.

ORZARI, I; MONQUERO, P. A; REIS, F. C; SABBAG, R. S.; HIRATA, A. C.; SORZARI, I. Germinação de espécies da família Convolvulaceae sob diferentes condições de luz, temperatura e profundidade de semeadura. Planta Daninha, Viçosa, v. 31, n. 1, p. 53-61, 2013.

PARIZOTO, C.; ESPANHOL, G. L.; GROTTO, V.; NESI, C. N.; MANTOVANI, A. Produção agroecológica de linhaça dourada (Linum usitatissimum) sob diferentes doses de cama de aves em diferentes espaçamentos entre linhas. Revista Brasileira de Agroecologia, Porto Alegre, v. 8, n. 2, p. 1-5, 2013.

RABETAFIKA, N. H.; REMOORTEL, V. V.; DANTHINE, S.; PAQUOT, M.; BLECKER, C. Flaxseed proteins: food uses and health benefits. International Journal of Food Science and Technology, United Kingdom, v. 46, n. 2, p. 221-228, 2011.

SAEIDI, G.; ROWLAND, G. G. The effect of temperature, seed colour and linolenic acid concentration on germination and seed vigour in flax. Canadian Journal of Plant Science, Ottawa, v. 79, n. 3, p. 315-319, 1999.

SHEN, S.; WU, F.; YANG, G.; WANG, Y.; HE, S. Seed germination and seedling emergence of Euryodendron excelsum H. T. Chang: implications for species conservation and restoration. Plant Species Biology, Malden, v. 31, n. 3, p. 233-239, 2015.

SOHRABIKERTABAD, S.; GHANBARI, A.; MOHAMAD, H. R. M.; MAHALATI, M. N.; GHEREKHLOO, J. Effect of desiccation and salinity stress on seed germination and initial plant growth of Cucumis melo. Planta Daninha, Viçosa, v. 31, n. 4, p. 833-841, 2013.

STEFANELLO, R.; NEVES, L. A. S.; ABBAD, M. A. B.; BOUCINHA, B. V. Germinação e vigor de sementes de chia (Salvia hispanica L. - Lamiaceae) sob diferentes temperaturas e condições de luz. Revista Brasileira de Plantas Medicinais, Botucatu, v. 17, n. 4, p. 1182-1186, 2015. Suplemento 3.

TAIZ, L.; ZEIGER, E. Fisiologia vegetal. 5. ed. Porto Alegre: Artimed, 2013. 954 p.

VILLELA, F. A.; DONI FILHO, L.; SEQUEIRA, E. L. Tabela de potencial osmótico em função da concentração de polietileno glicol 6000 e da temperatura. Pesquisa Agropecuária Brasileira, Brasília, v. 26, n. 11-12, p. 1957-1968, 1991. 